\title{
KARAKTERISASI SIFAT-SIFAT BIOKIMIA EKSTRAK KASAR LIPASE EKSTRASELULER BAKTERI Azospirillum sp.PRD1
}

\author{
Santi Nur Handayani ${ }^{1) *}$, Puji Lestari' ${ }^{1)}$, Oedjijono ${ }^{2)}$, Tri Joko Raharjo ${ }^{3)}$ dan \\ Sabirin Matsjeh ${ }^{3)}$ \\ ${ }^{1)}$ Prodi Kimia, MIPA FST Universitas Jenderal Soedirman, Purwokerto \\ ${ }^{2)}$ Fakultas Biologi Universitas Jenderal Soedirman, Purwokerto \\ 3) Jurusan Kimia Fakultas MIPA UGM \\ e-mail: santinurhandayani@yahoo.com
}

\begin{abstract}
ABSTRAK
Enzim lipase mempunyai peranan penting dalam katalis berbagai reaksi industri satu diantaranya pembuatan flavor melalui reaksi esterifikasi. Lipase adalah biokatalis yang berperan besar dalam aplikasi bioteknologi, seperti dalam sintesis biopolimer, biodiesel, produksi obat, dan produksi flavor. Peningkatan penggunaan lipase untuk industri mendorong dilakukan penelitian untuk mendapatkan sumber-sumber lipase baru. Sumber lipase yang potensial salah satunya adalah bakteri Azospirillum sp.PRD1 dari isolat lokal Laboratorium Mikrobiologi, Fakultas Biologi Universitas Jenderal Soedirman. Tujuan penelitian adalah untuk mendapatkan ekstrak kasar lipase dan menentukan karakteristik sifat-sifat biokimiawinya. Metode yang digunakan antara lain peremajaan bakteri Azospirillum sp.PRD1, dan produksi inokulum, penentuan waktu produksi optimum dan fase pertumbuhan bakteri, ekstraksi dan produksi ekstrak kasar lipase dan penentuan karakteristik sifat-sifat biokimiawinya. Hasil penelitian diperoleh ekstrak kasar lipase dari inokulum berumur 7 jam dan medium produksi dengan induser minyak zaitun yang diinkubasi selama 3 jam memiliki aktivitas spesifik 7,0547 Unit/mg. Lipase ekstrak kasar optimum pada $\mathrm{pH} 7$, suhu $40{ }^{\circ} \mathrm{C}$ dan waktu inkubasi selama 25 menit. Lipase merupakan metaloenzim dengan kofaktor $\mathrm{Zn}^{2+}, \mathrm{Mn}^{2+}, \mathrm{Hg}^{2+}, \mathrm{Ca}^{2+}, \mathrm{Co}^{2+}$ and $\mathrm{Mg}^{2+}$.
\end{abstract}

Kata kunci: Azospirillum sp.PRD1, aktivitas lipase, sifat biokimiawi

\section{BIOCHEMICAL PROPERTIES CHARACTERIZATION OF CRUDE EXTRACT OF LIPASE Azospirillum sp.PRD1 EXTRASELLULER BACTERIA}

\begin{abstract}
The enzyme lipase has an important role as catalyst in various industrial reactions, one of them in flavor via esterification reaction. Lipases play important role in various industries such as biotechnology application, biopolymer, biodiesel, pharmacy and flavors. The increasing of lipases requirements in industry is goading research to get new lipases resources committed. One of potential lipase resource is Azospirillum sp.PRD1 bacteria from Microbiology Laboratory, Biology Faculty University of Jenderal Soedirman. The research aims to get crude extract of lipase and investigate its biochemical characteristics. The method uses are rejuvenation of Azospirillum sp.PRD1 bacteria, inoculum production, determination of optimum production time and bacterium growth phase, extraction and production of lipase to get crude extract, and characterization the biochemical properties of
\end{abstract}


lipase crude extract. The research results that crude extracts lipase from ages inoculums at 7 hours and incubated in production medium with olive oil inducer until 3 hour had specific activity of $7.0547 \mathrm{Unit} / \mathrm{mg}$. The optimum lipase was achieve at $\mathrm{pH} 7,40{ }^{\circ} \mathrm{C}$ and incubation time at 25 menits. The lipase was a metalloenzym with its cofactor are $\mathrm{Zn}^{2+}$, $\mathrm{Mn}^{2+}, \mathrm{Hg}^{2+}, \mathrm{Ca}^{2+}, \mathrm{Co}^{2+}$ and $\mathrm{Mg}^{2+}$.

Keywords: Azospirillum sp.PRD1, lipase activity, biochemical characterization

\section{PENDAHULUAN}

Lipase (E.C.3.1.1.3) adalah enzim yang mengkatalisis reaksi hidrolisis ester asam karboksilat dalam lemak atau minyak dan sintesis monoester. Lipase mengkatalisis reaksi hidrolisis ester asam karboksilat atau reaksi sintesis monoester secara stereoselektif dan enantioselektif (Snellman and Colwell, 2004). Lipase merupakan enzim yang paling banyak digunakan sebagai katalis berbagai reaksi senyawa organik (Reetz, 2002). Lipase adalah biokatalis yang berperan besar dalam aplikasi bioteknologi, seperti dalam sintesis biopolimer, biodiesel, produksi obat, dan produksi flavor (Joseph et al., 2007).

Beberapa genus bakteri yang diketahui mampu menghasilkan enzim lipase adalah Pseudomonas, Alcaligenes, Sereatia dan Micrococcus (Fardiaz, 1993). Bakteri merupakan salah satu mikroba yang dapat menghasilkan enzim lipase, karena memiliki kemampuan hidup di berbagai lingkungan yang terdapat kandungan makanan atau nutrisi yang kompleks. Keuntungan memproduksi enzim dari mikroba adalah produksi enzim dapat ditingkatkan dalam skala besar dalam ruangan yang relatif terbatas (Suhartono, 1989).

Jenis bakteri yang digunakan dalam penelitian adalah bakteri Azospirillum sp.PRD1 selain mampu menambat nitrogen dan menghasilkan hormon pertumbuhan, juga mampu merombak bahan organik di dalam tanah. Oedjijono et al. (2007) telah melakukan penelitian tentang kemampuan isolat lokal bakteri Azospirillum sp.PRD1 koleksi Laboratorium Mikrobiologi Fakultas Biologi UNSOED dalam menghasilkan lipase dengan aktivitas Oedjijono et al. (2007) telah melakukan penelitian tentang kemampuan isolat lokal bakteri Azospirillum sp.PRD1 koleksi Laboratorium Mikrobiologi Fakultas Biologi UNSOED dalam menghasilkan lipase ekstrak kasarnya sebesar 0,25 U/100 mL. Oleh karena itu, perlu dilakukan produksi lipase dari bakteri Azospirillum sp.PRD1 yang meliputi peremajaan isolat murni, pembuatan kurva pertumbuhan bakteri Azospirillum sp.PRD1, dan pembuatan kurva produksi lipase. Perlu dilakukan juga karakterisasi lipase yang meliputi pengaruh suhu, $\mathrm{pH}$, waktu inkubasi optimum dan pengaruh adanya EDTA dan ion logam terhadap aktivitas lipase.

Berdasarkan hasil penelitian dan informasi tentang potensi lipase sebagai biokatalis dalam bidang industri, maka tujuan penelitian ini adalah untuk mendapatkan enzim lipase ekstrak kasar dari bakteri Azospirillum sp.PRD1, dan mengkarakterisasi sifat-sifat biokimiawinya yang dapat diaplikasikan sebagai biokatalis.

\section{METODE PENELITIAN}

\section{Alat dan Bahan}

Alat-alat penelitian yang digunakan adalah: cawan petri, tabung reaksi, erlenmeyer, labu takar, jarum ose, pHmeter "Hanna Instrumen", tabung sentrifugasi, mikro buret, statif, pipet mikro otomatis merk Wheaton Soccorex, 
sentrifuge "T 120", shaker incubator merk Memmert, shaker incubator merk Kottermann 4010, autoklaf, Spektrofotometer UV-Vis merk Shimidzu UV-1601, hot plate stirrer, dan pembakar Bunsen.

Bahan utama yang digunakan dalam penelitian ini adalah isolat murni Azospirillum sp.PRD1 koleksi Laboratorium Mikrobiologi Fakultas Biologi Unsoed, minyak zaitun dan minyak sawit komersial yang ada di pasaran. Bahan-bahan yang lain adalah: medium NA, medium NB, gum arab, buffer Na-Asetat, buffer Na-Fosfat, buffer Tris-HCl, buffer fosfat $\mathrm{pH} \mathrm{7,}$ $\mathrm{CaCl}_{2} 110 \mathrm{mM}, \mathrm{MgCl}_{2} 110 \mathrm{mM}, \mathrm{CoCl}_{2}$ $110 \mathrm{mM}, \mathrm{CuCl}_{2} 110 \mathrm{mM}, \mathrm{ZnCl}_{2} 110$ $\mathrm{mM}$, aseton, etanol, indikator fenolftalein, $\mathrm{NaOH} 50 \mathrm{mM}$, EDTA, Follin Ciocalteau, aquades, Bovine Serum Albumin (BSA), fenolftalein, dan pereaksi Lowry.

\section{Prosedur Penelitian}

\section{Peremajaan isolat Azospirillum sp.PRD1}

Peremajaan dilakukan pada isolat murni Azospirillum sp.PRD1 dari stok murni dari freezer pada medium gliserol dengan menumbuhkan pada medium Nutrien Broth (NB) dan diinkubasi selama 2 x 24 jam di dalam inkubator pada suhu $30{ }^{\circ} \mathrm{C}$. Pertumbuhan koloni ditandai adanya kekeruhan pada medium.

\section{Pembuatan inokulum Azospirillum sp.PRD1}

Isolat murni Azospirillum sp.PRD1 hasil peremajaan, kemudian diambil $6 \mathrm{~mL}$ dan diinokulasikan pada medium NB, selanjutnya diinkubasi pada shaker bath dengan kecepatan $125 \mathrm{rpm}$ pada suhu $30{ }^{\circ} \mathrm{C}$ selama 25 jam. Setiap 1 jam sekali sampel diambil dan diukur OD (optical density) dengan spektrofotometer visibel pada $\lambda 600 \mathrm{~nm}$ untuk menentukan kurva pertumbuhan sel. Inokulum yang diinokulasikan ke dalam medium produksi adalah inokulum yang berada pada fase eksponensial berdasarkan kurva pertumbuhan sel.

\section{Pembuatan kurva produksi lipase}

Kurva produksi lipase dibuat untuk menentukan masa inkubasi yang menghasilkan lipase dengan aktivitas tertinggi. Inokulum sebanyak $20 \mathrm{ml}$ diinokulasikan ke dalam $200 \mathrm{~mL}$ medium NB (sebagai medium fermentasi) dalam Labu Erlenmeyer $500 \mathrm{~mL}$ yang diperkaya dengan $1 \%$ minyak zaitun (olive oil) sebagai induser (Prazeres et al., 2006). Medium fermentasi yang mengandung inokulum diinkubasi dalam shaker bath dengan kecepatan $125 \mathrm{rpm}$ pada suhu $30{ }^{\circ} \mathrm{C}$ selama $2 \times 24$ jam. Pengambilan cuplikan dilakukan setiap 6 jam sekali. Sebagian cairan fermentasi diukur absorbansinya menggunakan spektrofotometer visibel pada $\lambda 600 \mathrm{~nm}$ untuk mengetahui kepadatan selnya, sebagian disentrifus dengan sentrifus dingin (6000 rpm, $\left.4{ }^{\circ} \mathrm{C}, 10 \mathrm{menit}\right)$. Supernatan yang didapat merupakan ekstrak kasar lipase dan diukur aktivitasnya.

\section{Produksi lipase}

Produksi lipase dilakukan dengan cara yang sama seperti pembuatan kurva produksi dengan waktu inkubasi yang menghasilkan aktivitas lipase tertinggi. Produksi lipase dilakukan dalam Labu Erlenmeyer 1 liter dengan medium fermentasi yang diperkaya emulsi minyak zaitun (olive oil) sebagai induser sebanyak $750 \mathrm{ml}$. Ekstrak kasar lipase yang didapat diukur volume, aktivitas dan kadar proteinnya. Kadar protein ditentukan menurut metode Lowry (Bollag et al., 1996). Karakterisasi lipase yang dilakukan meliputi suhu optimum, $\mathrm{pH}$ optimum, pengaruh EDTA dan ion logam terhadap aktivitas lipase.

\section{Pengukuran aktivitas lipase}

Pengukuran aktivitas lipase menggunakan metode titrimetri yang 
diadaptasi dari Prazeres et al. (2006). Substrat yang digunakan adalah emulsi minyak sawit $25 \%$ dalam larutan gum arab $7 \%$. Campuran reaksi enzim terdiri dari: $5 \mathrm{ml}$ emulsi minyak kedelai, $4 \mathrm{ml}$ buffer fosfat $50 \mathrm{mM} \mathrm{pH} 7$ dan $1 \mathrm{ml} \mathrm{CaCl} 2$ $110 \mathrm{mM}$, diinkubasi selama 5 menit pada suhu $35{ }^{\circ} \mathrm{C}$, kemudian ditambahkan $1 \mathrm{ml}$ enzim dan inkubasi dilanjutkan selama 30 menit. Reaksi dihentikan dengan penambahan $5 \mathrm{ml}$ aseton : etanol (1:1). Asam lemak yang dibebaskan dititrasi menggunakan $\mathrm{NaOH} 50 \mathrm{mM}$. Aktivitas lipase dapat ditentukan dari volume $\mathrm{NaOH}$ yang dibutuhkan untuk titasi sampel dikurangi $\mathrm{NaOH}$ yang dibutuhkan untuk titrasi kontrol. Satu unit (U) aktivitas lipase diartikan sebagai banyaknya enzim yang menghasilkan $1 \mu$ mol asam lemak bebas per menit.

Unit aktivitas enzim $=$

$(\mathrm{V} \mathrm{NaOH}$ sampel $-\mathrm{V} \mathrm{NaOH}$ kontrol $) \times \frac{100}{\text { volume enzim }(\mathrm{mL})}$

\section{Penetapan Kadar Protein Lipase dengan Metode Lowry (Bollag et al., 1996)}

Kadar protein ekstrak kasar lipase dan hasil pemurnian ditetapkan untuk menghitung aktivitas spesifik lipase. Serangkaian larutan standar protein (BSA) dengan konsentrasi 0,$2 ; 0,4 ; 0,6$; 0,8 ; dan $1 \mathrm{mg} / \mathrm{ml}$ dalam buffer Tris- $\mathrm{HCl}$ pH 8 disiapkan. Sebanyak 0,5 ml larutan protein standar dan larutan enzim dimasukkan ke dalam tabung reaksi yang berbeda, kemudian ditambah dengan $5 \mathrm{ml}$ pereaksi C, dibiarkan pada suhu kamar selama 10 menit, selanjutnya ditambahkan $0,5 \mathrm{ml}$ pereaksi $\mathrm{E}$ dan dikocok. Larutan dibiarkan selama 30 menit. Larutan pada tiap tabung reaksi diukur absorbansinya dengan spektrofotometer visibel pada panjang gelombang $750 \mathrm{~nm}$.

\section{Karakterisasi Lipase}

Penentuan pengaruh pH terhadap aktivitas lipase (Prazeres, 2006, Faiz et al., 2007)

Pengaruh $\mathrm{pH}$ terhadap aktivitas lipase ditentukan pada $\mathrm{pH}$ antara 4-9 dengan berbagai variasi buffer yang sesuai dengan konsentrasi $50 \mathrm{mM}$. Prosedur pengujian aktivitas lipase pada berbagai $\mathrm{pH}$ dilakukan dengan prosedur yang sama dalam pengukuran aktivitas lipase.

\section{Penentuan pengaruh suhu terhadap aktivitas lipase (Faiz et al., 2007) \\ Penentuan pengaruh suhu} terhadap aktivitas lipase ditentukan pada beberapa variasi suhu yakni $35,40,45$, 50, 55, 60, 65, 70, $75{ }^{\circ} \mathrm{C}$ pada larutan emulsi (substrat) dengan $\mathrm{pH}$ optimum enzim yang telah didapat sebelumnya. Pengukuran aktivitas lipase pada berbagai suhu digunakan prosedur yang sama dengan pengukuran aktivitas lipase.

Pengaruh berbagai ion logam, serta EDTA terhadap aktivitas lipase ( Faiz, et al., 2007)

Pengaruh ion logam terhadap aktivitas lipase ditentukan dengan menambahkan $1 \mathrm{mM}$ ion $\mathrm{Cu}^{2+}, \mathrm{Ca}^{2+}$, $\mathrm{Mg}^{2+} \mathrm{Zn}^{2+}$ dan $\mathrm{Co}^{2+}$ serta EDTA. Setiap ion logam, serta EDTA dengan konsentrasi $1 \mathrm{mM}$ ditambahkan ke dalam lipase dengan perbandingan $1: 1$. Kontrol dibuat dengan tanpa penggunaan ion logam, dan EDTA pada lipase. Penentuan aktivitas lipase dilakukan sama dengan uji aktivitas.

\section{HASIL DAN PEMBAHASAN}

\section{Produksi Lipase}

Produksi lipase dari isolat bakteri Azospirillum sp.PRD1 diawali dengan peremajaan isolat murni, pembuatan 
kurva pertumbuhan bakteri Azospirillum sp.PRD1, dan pembuatan kurva produksi lipase. Peremajaan isolat bakteri Azospirillum sp.PRD1 dilakukan pada medium NA miring.

Isolat bakteri Azospirillum sp.PRD1 hasil peremajaan selanjutnya digunakan dalam pembuatan kurva pertumbuhan bakteri Azospirillum sp.PRD1. Penentuan fase eksponensial pertumbuhan bakteri dilakukan dengan cara menginokulasikan isolat bakteri ke dalam medium NB dan dan diinkubasi selama 24 jam. Setiap 1 jam sekali diukur kepadatan selnya dengan menggunakan spektrofotometer visibel pada $\lambda 600 \mathrm{~nm}$. Pertumbuhan bakteri Azospirillum sp.PRD1 ditandai dengan perubahan medium NB menjadi keruh. Pembuatan kurva pertumbuhan bakteri Azospirillum sp.PRD1 dilakukan untuk menentukan umur inokulum pada fase eksponensialnya. Bakteri Azospirillum sp.PRD1 pada fase eksponensial digunakan sebagai inokulum untuk produksi lipase. Kurva pertumbuhan bakteri Azospirillum sp.PRD1 dapat dilihat pada Gambar 1.

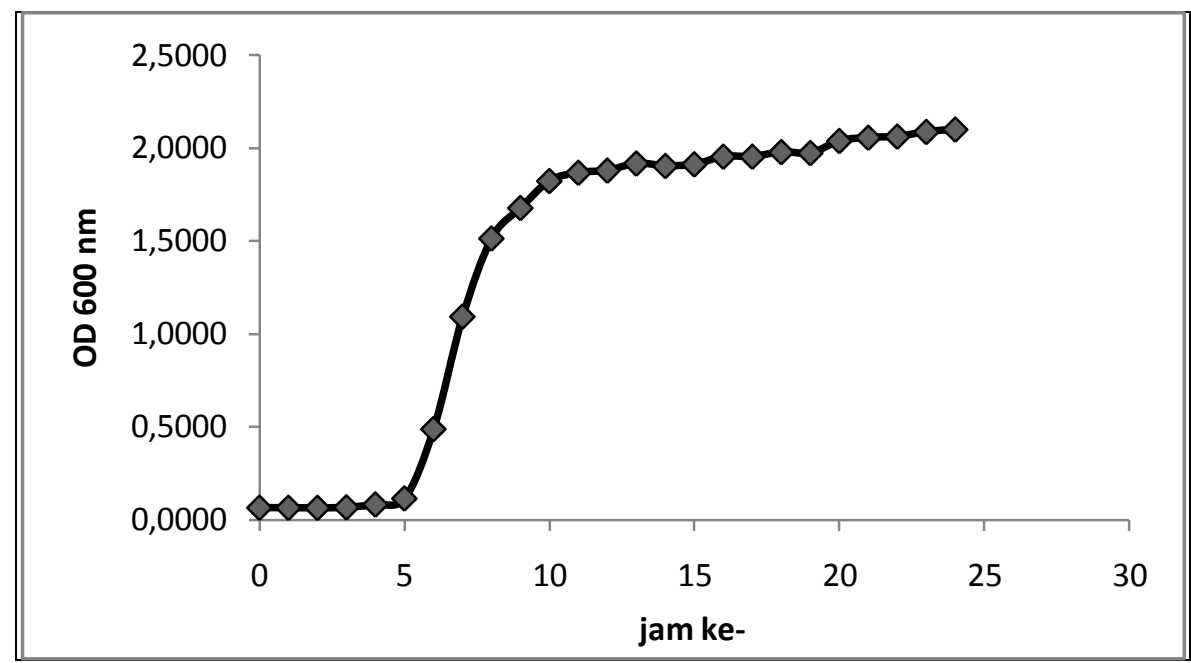

Gambar 1. Kurva Pertumbuhan Bakteri Azospirillum sp. PRD1

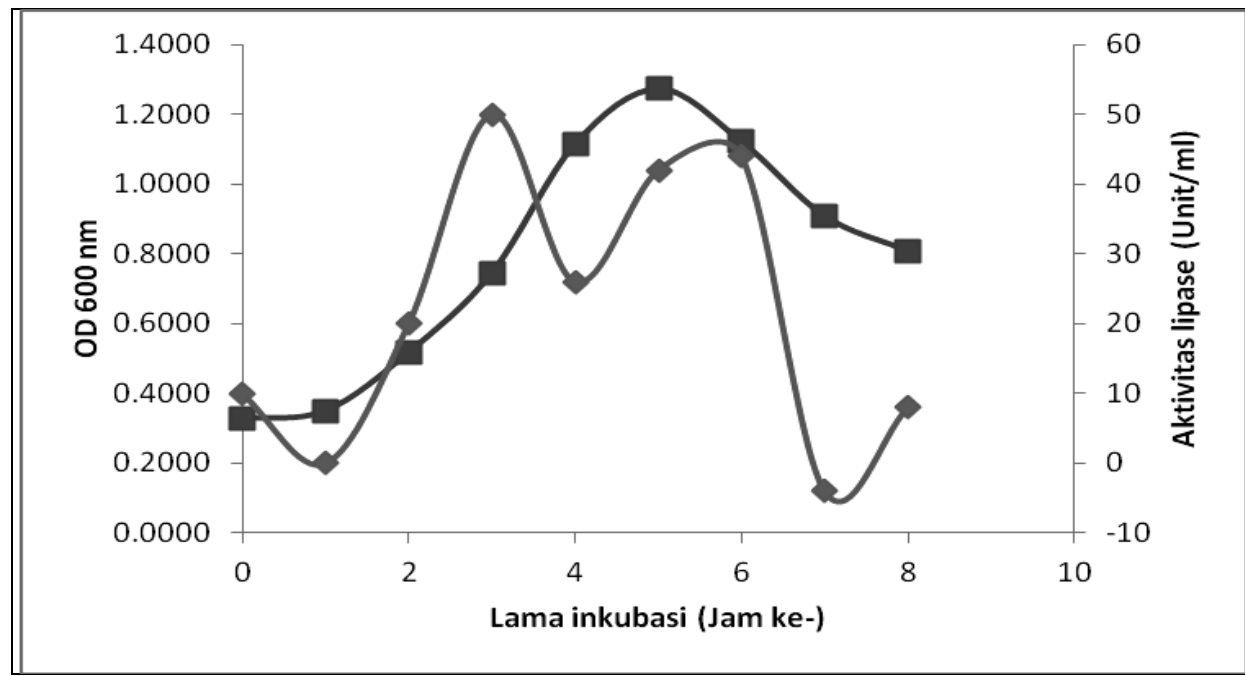

Gambar 2. Kurva optical density dan aktivitas Lipase Ekstrak Kasa r Bakteri Azospirillum sp. PRD.1 
Berdasarkan hasil penelitian (Gambar 1) diperoleh bahwa isolat bakteri Azospirillum sp.PRD1 memiliki laju pertumbuhan paling cepat pada waktu inkubasi 7 jam dengan nilai OD sebesar 1,0929. Pembuatan kurva produksi lipase bertujuan untuk mengetahui waktu inkubasi yang menghasilkan lipase dengan aktivitas tertinggi.

Penentuan waktu produksi optimum lipase dibuat untuk menentukan waktu inkubasi yang menghasilkan lipase dengan aktivitas tertinggi. Isolat bakteri yang berumur 7 jam dimasukan ke dalam media produksi dengan induser minyak zaitun, inkubasi dilakukan selama 3 jam. Hasil pengukuran kepadatan sel dan aktivitas enzim lipase yang dihasilkan oleh isolat bakteri Azospirillum sp.PRD1 ditampilkan pada Gambar 2.

Berdasarkan hasil penelitian yang ditampilkan pada Gambar 2 menunjukkan bahwa Azospirillum sp. PRD1 mengalami fase eksponensial pada inkubasi jam ke-0 sampai jam ke-4, selanjutnya fase stasioner setelah inkubasi 4 jam. Azospirillum sp. PRD1 pada medium produksi tidak mengalami fase lag (fase adaptasi), karena bakteri yang dimasukkan ke dalam medium produksi telah mengalami adaptasi pada medium inokulum sehingga bakteri pada medium produksi telah siap membelah (Volk dan Wheelar, 1988). Aktivitas lipase meningkat pada waktu inkubasi 2 sampai 4 jam. Aktivitas tertinggi lipase tercapai pada fase log akhir dengan lama inkubasi 3 jam dan aktivitas sebesar $40 \mathrm{U} / \mathrm{ml}$.

Produksi lipase dilakukan dengan menumbuhkan inokulum pada fase eksponensial yaitu inokulum umur 7 jam ke dalam medium produksi. Medium produksi selanjutnya disentrifugasi (3500 rpm, $4{ }^{\circ} \mathrm{C}$, 10 menit). Supernatan yang diperoleh merupakan ekstrak kasar lipase. Volume ekstrak kasar lipase yang dihasilkan adalah $1092 \mathrm{~mL}$ dengan aktivitas sebesar $12 \mathrm{Unit} / \mathrm{mL}$, kadar protein $1,7010 \mathrm{mg} / \mathrm{mL}$, dan aktivitas spesifik 7,0547 Unit. Karakterisasi sifatsifat biokimiawi terhadap ekstrak kasar lipase yang dilakukan adalah penentuan suhu dan $\mathrm{pH}$ optimum, pengaruh EDTA dan ion logam terhadap aktivitas lipase.

\section{Karakterisasi Lipase}

\section{Penentuan pH optimum}

Penentuan $\mathrm{pH}$ optimum enzim lipase dilakukan pada suhu $30^{\circ} \mathrm{C}$ dengan variasi $\mathrm{pH} 5$ - 9. Hasil penelitian ditampilkan pada Gambar 3.

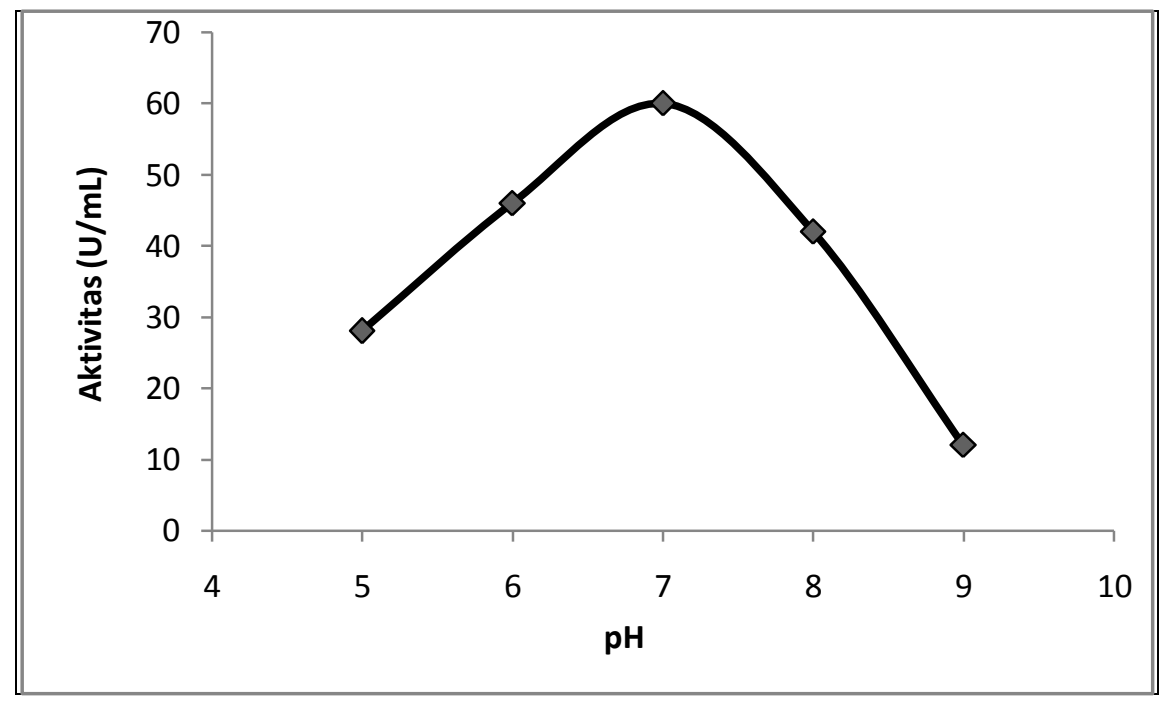

Gambar 3. Grafik penentuan $\mathrm{pH}$ optimum aktivitas lipase 
Berdasarkan hasil penelitian, $\mathrm{pH}$ optimum lipase 7 dengan nilai aktivitas $60 \mathrm{U} / \mathrm{ml}$ (Gambar 3). Pada kondisi pH optimum, gugus pemberi dan penerima proton yang penting pada sisi katalitik enzim mempunyai struktur tiga dimensi yang paling sesuai dengan substrat sehingga dapat mengikat substrat dengan tepat, membentuk kompleks enzimsubstrat dan menghasilkan produk secara maksimum (Nurhasanah dan Herasari, 2008). Aktivitas lipase diluar suhu optimum rendah karena enzim mengalami denaturasi. Pada $\mathrm{pH}$ rendah, enzim terprotonasi dan kehilangan muatan negatifnya, substrat terionisasi sehingga kehilangan muatan positifnya (Page, 1989).

Handayani dan Sulistyo (2005) mendapatkan bahwa lipase yang diproduksi dari Pseudomonas aeregenes dan $B$. substilis mempunyai $\mathrm{pH}$ optimum pad pH 7 dengan aktivitas masing-masing $5,81 \mu \mathrm{mol} / \mathrm{menit}$ dan $5,85 \mu \mathrm{mol} / \mathrm{menit}$.

\section{Penentuan Suhu Optimum}

Penentuan suhu optimum dilakukan pada $\mathrm{pH}$ optimum yaitu 7 . Hasil penelitian diperlihatkan pada Gambar 4.

Berdasarkan hasil penelitian, suhu optimum lipase adalah $40{ }^{\circ} \mathrm{C}$ dengan nilai aktivitas sebesar $108 \mathrm{U} / \mathrm{ml}$ (Gambar 4). Handayani dan Sulistyo (2005) melaporkan bahwa lipase yang diperoleh dari B.substilis mempunyai suhu optimum pada suhu $40{ }^{\circ} \mathrm{C}$ dengan aktivitas sebesar 5,98 $\mu \mathrm{mol} / \mathrm{menit}$. Menurut Gupta, et al. (2004) lipase yang diisolasi dari bakteri memiliki suhu optimum pada kisaran 30-60 ${ }^{\circ} \mathrm{C}$, sedangkan menurut Volk dan Wheeler (1988) kebanyakan enzim mempunyai aktivitas optimum pada suhu antara 30 dan $40{ }^{\circ} \mathrm{C}$.

Aktivitas enzim terhadap suhu dipengaruhi oleh energi kinetik enzim dan substrat untuk saling bertumbukan. Meningkatnya suhu menyebabkan energi kinetik meningkat. Aktivitas enzim meningkat seiring dengan meningkatnya suhu dan menurun setelah mencapai suhu optimum. Pada suhu rendah, sebelum suhu optimum, aktivitas lipase lebih rendah daripada aktivitas lipase di suhu optimum. Hal ini karena tumbukan yang terjadi antara enzim dengan substrat intensitasnya masih rendah sehingga kompleks enzim-substrat yang terbentuk sedikit dan produk yang dihasilkan juga sedikit. Peningkatan suhu sampai suhu optimum meningkatkan tumbukan yang terjadi antara enzim dengan substrat sehingga aktivitas enzim juga meningkat. Pada suhu optimum, tumbukan antara enzim dengan substrat sangat efektif sehingga kompleks enzim-substrat semakin mudah terbentuk dan produk yang dihasilkan juga meningkat. Peningkatan suhu di atas suhu optimum menyebabkan aktivitas enzim menurun. Hal ini karena enzim terdenaturasi sehingga terjadi perubahan struktur tiga dimensi enzim yang menyebabkan substrat sukar berikatan dengan sisi aktif enzim akibatnya aktivitas enzim menurun (Sadikin, 2002).

\section{Pengaruh Penambahan EDTA dan Ion Logam terhadap Aktivitas Lipase}

Penentuan pengaruh penambahan EDTA dan ion logam terhadap aktivitas lipase dilakukan pada $\mathrm{pH}$ optimum 7 dan suhu optimum $40^{\circ} \mathrm{C}$. Ion-ion logam yang digunakan adalah $\mathrm{Zn}^{2+}, \mathrm{Mn}^{2+}, \mathrm{Hg}^{2+}$, $\mathrm{Ca}^{2+}, \mathrm{Co}^{2+}, \mathrm{Mg}^{2+}, \mathrm{Ba}^{2+}, \mathrm{Cu}^{2+}$, dan $\mathrm{Mg}^{2+}$ serta EDTA. Hasil penelitian ditampilkan Gambar 5.

Uji pengaruh penambahan EDTA dan ion logam menunjukkan bahwa penambahan EDTA menurunkan aktivitas relatif lipase menjadi $75 \%$ (Gambar 5). EDTA akan mengkhelat logam pada sisi aktif lipase sehingga struktur enzim berubah dan enzim kehilangan sisi katalitiknya (Sindumarta dan Natalis, 1999). Hal ini menunjukkan bahwa ekstrak kasar lipase merupakan 
metaloenzim, yaitu kelompok enzim yang mempunyai ikatan yang erat dengan logam. Penambahan ion $\mathrm{Zn}^{2+}, \mathrm{Mn}^{2+}$, $\mathrm{Hg}^{2+}, \mathrm{Ca}^{2+}, \mathrm{Co}^{2+}, \mathrm{Mg}^{2+}$ meningkatkan aktivitas relatif ekstrak kasar lipase masing-masing menjadi 435\%, 370\%, $300 \%, 195 \%, 180 \%, 140 \%, 110 \%$. Hal ini menunjukkan bahwa ion-ion tersebut merupakan kofaktor bagi ekstrak kasar lipase. Ion $\mathrm{Ba}^{2+}$ dan $\mathrm{Cu}^{2+}$, menurunkan aktivitas relatif ekstrak kasar lipase menjadi $98 \%$ dan $20 \%$. Oleh karena itu, ion $\mathrm{Ba}^{2+}$ dan $\mathrm{Cu}^{2+}$ merupakan inhibitor bagi ekstrak kasar lipase. Bhumibhamon, et al., (2002) menyebutkan bahwa aktivitas lipase yang diperoleh dari Pseudomonas sp. KLB1 ditingkatkan oleh ion $\mathrm{Ca}^{2+}$ dengan aktivitas relatif sebesar $151,59 \%$ dan dihambat oleh ion $\mathrm{Co}^{2+}$ dan EDTA dengan aktivitas relatif sebesar $75,84 \%$ dan $95,63 \%$. Kofaktor pada umumnya merupakan molekul anorganik yang berikatan dengan enzim untuk menjaga bentuk sisi aktif enzim agar tetap berada pada konformasi yang tepat, sehingga enzim dapat berikatan dengan substrat membentuk kompleks enzim-substrat dan membentuk produk (Manitto, 1992).

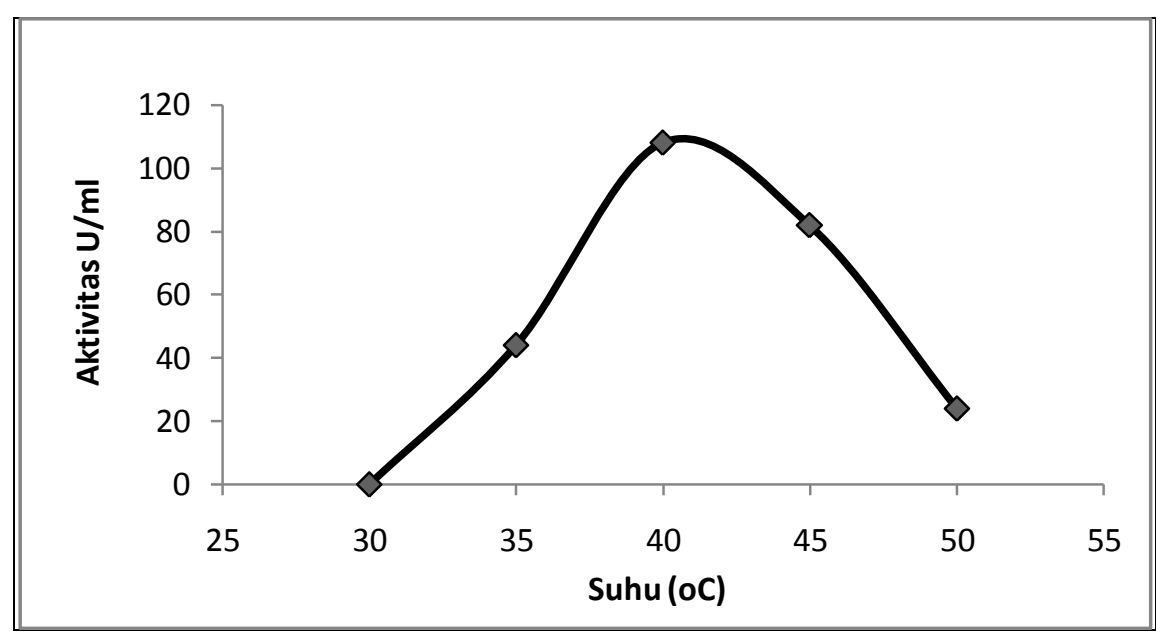

Gambar 4. Grafik penentuan suhu optimum aktivitas lipase

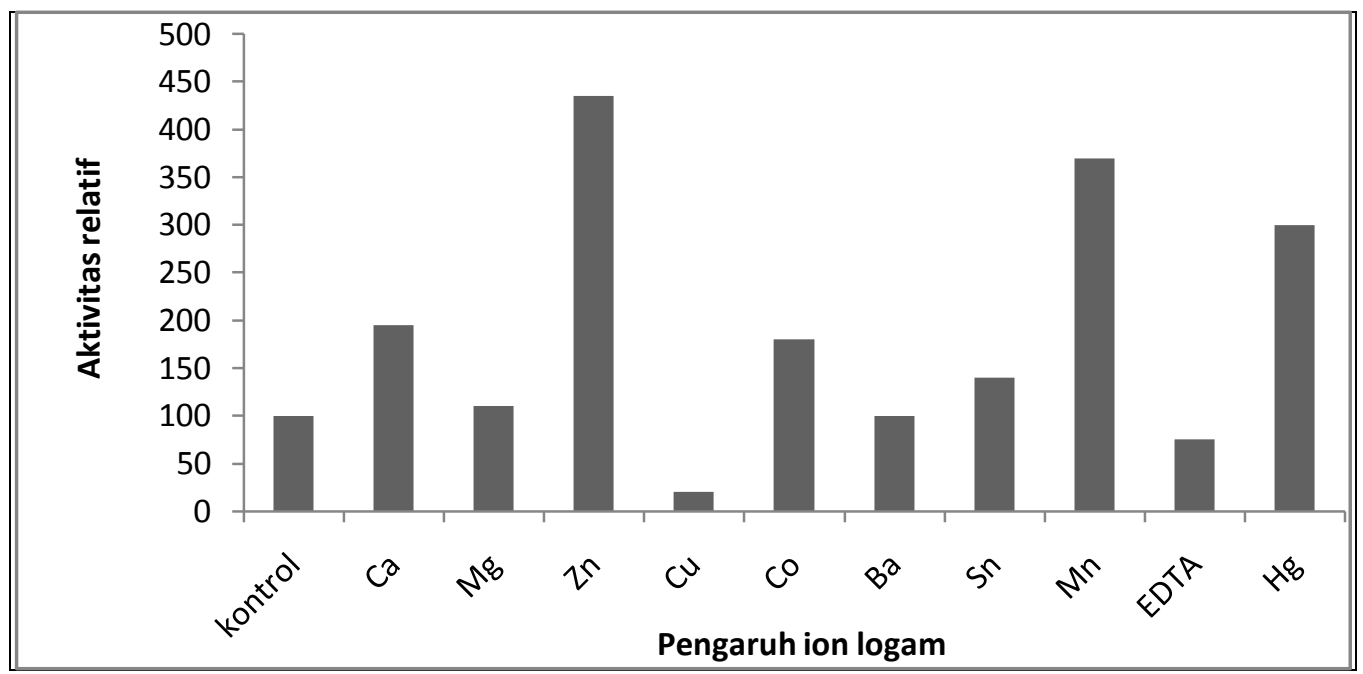

Gambar 5. Histogram pengaruh berbagai ion logam terhadap aktivitas relatif ekstrak kasar lipase 


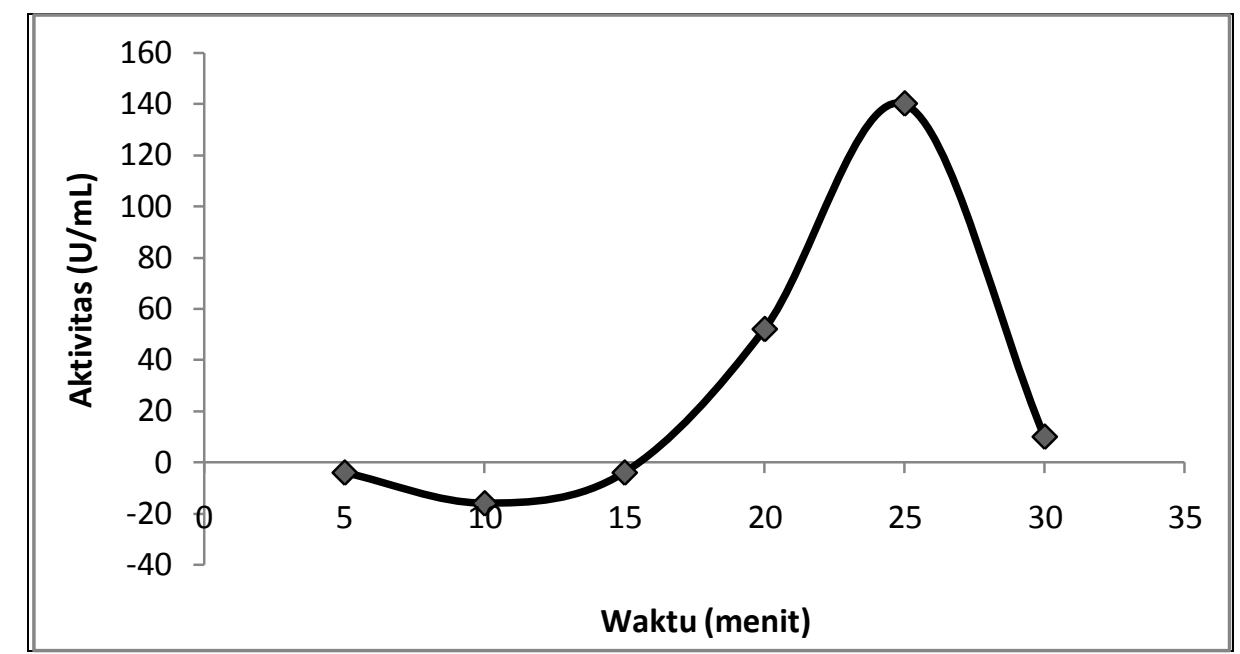

Gambar 6. Grafik waktu inkubasi optimum aktivitas ekstrak kasar lipase

\section{Pengaruh Waktu Inkubasi}

Penentuan pengaruh waktu inkubasi terhadap aktivitas lipase dilakukan pada $\mathrm{pH}$ optimum 7 dan suhu optimum $40{ }^{\circ} \mathrm{C}$. Hasil penelitian ditampilkan pada Gambar 6. Hasil penelitian menunjukkan bahwa aktivitas lipase paling tinggi dalam waktu inkubasi 25 menit dengan aktivitas sebesar 140 $\mathrm{U} / \mathrm{mL}$. Hal ini diduga karena lipase tidak dapat terlalu lama bereaksi dengan substrat sehingga aktivitas lipase mulai menurun setelah waktu inkubasi 25 menit. Nurhasanah dan Herasari (2008) melaporkan bahwa lipase hasil pemurnian yang dihasilkan oleh bakteri lokal memiliki waktu inkubasi optimum 10 menit dengan suhu optimum $45^{\circ} \mathrm{C}$.

\section{KESIMPULAN DAN SARAN}

\section{A. Kesimpulan}

1. Inokulum yang digunakan dalam produksi lipase dari bakteri Azospirillum sp.PRD1 berumur 7 jam dan medium produksi dengan induser minyak zaitun yang dinkubasi selama 3 jam lipase.

2. Ekstrak kasar lipase dari bakteri Azospirillum sp.PRD1 yang diperoleh memiliki aktivitas spesifik 7,0547 Unit/mg.
3. Karakteristik sifat-sifat biokimiawi ekstrak kasar lipase Azospirillum sp.PRD1 adalah adalah memiliki suhu optimum $40{ }^{\circ} \mathrm{C}, \mathrm{pH}$ optimum 7 , dan waktu inkubasi optimum 25 menit ; merupakan metaloenzim dengan kofaktornya adalah ion logam $\mathrm{Zn}^{2+}$, $\mathrm{Mn}^{2+}, \mathrm{Hg}^{2+}, \mathrm{Ca}^{2+}, \mathrm{Co}^{2+}$ dan $\mathrm{Mg}^{2+}$.

\section{B. Saran}

Perlu dilakukan penelitian lebih lanjut untuk memurnikan ekstrak kasar lipase, kemudian ditentukan karakteristik sifat biokimiawinya dan mengetahui bobot molekul lipase dan sekuen asam amino penyusun lipase.

\section{UCAPAN TERIMAKASIH}

Ucapan terima kasih disampaikan kepada Lembaga Penelitian UNSOED dan Dirjen Dikti Kemendiknas yang telah memberikan dana Hibah PEKERTI Tahun 2010 bagi terlaksananya penelitian ini. Ucapan terima Kasih juga disampaikan kepada Joharatul Laela S.Si dan Maria Ulfah S.Si, dan dua mahasiswa kimia Siti Amriyatun (H1A006001) dan Andin (H1A006033) yang telah membantu terlaksananya penelitian ini. 


\section{DAFTAR PUSTAKA}

Bhumibhamon, O., J. Dinda dan S. Fungthong., 2002, Isolation and Characterization of Pseudeumonas sp. KLB 1 Lipase from High Fat Wastewater (online), http://www.thaiscience.info/articl e, Diakses tanggal 5 Oktober 2010.

Bollag, D. M., S. J. Edelstein dan M. D. Rozycki, 1996, Protein Methode $1^{\text {st }}$ Edition, John Willey and sons, Inc., New York.

Faiz, O., N. Saghlam., A. Colak, A., S. Canakci dan A. O. Belduz, 2007, Determination and Characterization of Thermostable Esterolytic Activity from a Novel Thermophilic Bacterium Anoxybacillus gonensis A4, Journal of Biochemistry and Molecular Biology ,Vol. 40, 588594.

Fardiaz, S, 1993, Analisis Mikrobiologi Pangan, Raja Grafindo Persada, Jakarta..

Joseph, B., P. W. Ramteke., G. Thomas, dan N. Shrivastava, 2007, Standard Review Cold-active microbial Lipases: a versatile tool for industrial applications, Biotechnology and Molecular Biology Review, Vol.2, No.2, 039048.

Handayani, R dan J. Sulistyo, 2005, Transesterifikasi Ester Asam Lemak Melalui Pemanfaatan Teknologi Lipase, Biodiversitas, Vol. 6, 164-167.

Manitto, P.,1992, Biosintesis Produk Alam, IKIP Semarang Press, Semarang.
Oedjijono, D. Ryandini, dan I.D.S.A.P. Permiarti, 2007, Aktivitas Enzimatis Azospirillum pada Substrat Onggok dan Dedak, Laporan penelitian Program Penelitian Dasar (Tidak dipublikasikan), Fakultas Biologi Unsoed, Purwokerto.

Prazeres, J.N., Cruz, J.A., dan Pastore, G.M., 2006, Characterization of Alkaline Lipase from Fusarium oxysporum and the Effect of Different Surfactants and Detergents on the Enzyme Activity, Brazilian Journal of Microbiology, Vol. 37,505-509

Putranto, R.A., D. Santosa, T. Panji, Suharyanto, dan A. Budiani., 2006, Karakterisasi Gen Penyandi Lipase dari Kapang Rhizopus oryzae dan Absidia corymbifera, (on- line). http://www.ipard.com, Diakses Tanggal 20 Maret 2009

Reetz, M.T, 2002, Lipases as Practical Biocatalyst. Current Opinion in Chemical Biology, Vol.6, 145-150.

Sadikin, M., 2002, Biokimia Enzim. Widya Medika, Jakarta.

Sindumarta, M. dan D. Natalia, 1999, Biokimia I: Struktur dan Katalis, Penerbit ITB, Bandung.

Snellman, E.A dan R.R. Colwell., 2004, Acinetobacter Lipases: Molecular Biology, Biochemaical Properties and Biotechnological Potential, Journal of Industrial Microbiology \& Biotechnology, Review Paper.

Suhartono, M.T., 1989, Enzim dan Bioteknologi, PAU Bioteknologi IPB, Bogor.

Volk, W. A dan M. F. Wheelar., 1988, Mikrobiologi Dasar, Erlangga, Jakarta. 